\title{
MODE REPRESENTASI IDE DALAM BELAJAR MATEMATIKA
}

\author{
Agung Hartoyo \\ Pend. Matematika, FKIP, Universitas Tanjungpura
}

\begin{abstract}
The aims of this research were to investigate development processes and to know the reason that student pushes to changes her representation idea in problem solving. Representation's developmental path in solving problem at starts by building imagery in imagistic's system drawned out by verbal representation by forms representation of rethorica's equation, and develops it as equation syncopated. She does several times change her representation. The Changing of representation impelled by imagistic tactile system; imbalance in cognitive stucture, comptency of information assimilation on problem, ordinary procedure utilized by respondent in solving problem, and characters and equality relationship of algebra or arithmetica's structures.
\end{abstract}

\section{Keywords : representations}

\section{Pendahuluan}

Ada dua fungsi yang dijalankan dalam pembelajaran matematika sekolah, yaitu mengembangkan kemampuan mengomunikasikan gagasan melalui model matema-tika, dan mengembangkan kemampuan, kecakapan atau kemahiran matematika. Karena fungsi tersebut, maka kecakapan menggunakan berbagai simbol, grafik, tabel, diagram, merumuskan - menafsirkan - menyelesaikan model matematika untuk memperjelas keadaan atau masalah merupakan bagian penting dalam pembelajaran matematika. Lesh, Post, \& Behr (Hiebert \& Carpenter, 1992); Janvier, dkk. (1987); dan Goldin (1987) mengemukakan bahwa pengungkapan ide-ide matematika dengan menggunakan berbagai modus seperti : bahasa lisan, bahasa tulis, simbol, gambar, di-agram, model, grafik, atau menggunakan anggota fisik dikatakan sebagai representasi ide. Itu berarti bahwa kecakapan membangun representasi merupakan bagian esensial dalam pembelajaran matematika di samping kecakapan pemahaman konsep, pena-laran, komunikasi, dan pemecahan masalah.

Representasi ide-ide matematika dalam berbagai cara merupakan pondamen untuk memahami dan menggunakan ide-ide tersebut (NCTM, 2000). Kaput (1987) dan Janvier (1987) berpendapat bahwa representasi sangat berperan dalam pembe-lajaran matematika. Berbagai representasi, seperti diagram, grafik, ekspresi bilangan basis-10 atau biner, pecahan, atau ekspresi- 
ekspresi simbolik merupakan komponen utama dalam kurikulum matematika sekolah. Bila para siswa telah mengenal repre-sentasi dan dapat merepresentasikan ide-idenya, mereka mendapat sekumpulan alat untuk mengembangkan kapasitasnya dalam berpikir matematis. Oleh karena itu, re-presentasi harus diperlakukan sebagai unsur penting di dalam mendorong siswa memahami konsep matematika dan relasi-relasinya, berkomunikasi dengan berargumentasi, matematika, mengenali keterkaitan antar konsep matematika, dan menerapkan matematika ke situasi masalah realistis melalui pemodelan. Secara eksplisit NCTM (2000) menetapkan representasi sebagai salah satu standar kompetensi dalam pembe-lajaran matematika sekolah.

Pada kasus pemecahan masalah, Yamada (2000) mengidentifikasi banyak hal yang dilakukan responden ketika membangun representasi mental dari pernyataan masalah. Representasi yang dibangun selama proses pemecahan masalah sering mengalami perubahan. Sebagai contoh, setelah membaca pernyataan masalah sebagian besar siswa membangun representasi verbal, tetapi pada tahap akhir pemecahan masalah representasi itu berbeda dari representasi sebelumnya melalui banyak cara, misalnya dengan menambah representasi notasi formal. Representasi internal yang dibangun secara mental dari pernyataan permasalahan diduga berkaitan dengan tindakan imitasi untuk melakukan tiruan atas situasi atau pengalaman yang dimiliki.
Untuk menginterpretasi berbagai hal yang berkaitan dengan representasi masalah, penelitian ini bersandar pada dua perspektif pokok. Perspektif pertama adalah model Goldin (1987); kemudian dikembangkan oleh Thomas, Mulligan, \& Goldin, (2002) yaitu model kompetensi dalam pemecahan masalah matematika yang didasarkan pada sistem representasi. Perspektif kedua adalah aktivitas eksternal siswa selama menye-lesaikan tugas pemecahan masalah.

Dalam menetapkan karakteristik tugas-tugas pemecahan masalah dan mendes-kripsikan proses kognitif pada pembentukan representasi eksternal, Goldin (1987) membedakan sistem representasi kognitif internal pada pemecahan masalah atas lima sistem representasi. Model Goldin tersebut meliputi : (1) sistem sintaktik / verbal (2) sistem imagistik (3) sistem notasi formal (4) sistem perencanaan, monitor (5) sistem representasi affektif. Dari prasurvey yang berkaitan dengan representasi (Hartoyo, 2002) ditemukan beberapa respon siswa dalam mememecahkan masalah. Respon mereka antara lain : pada penyelesaian kasus-kasus khusus mereka menggunakan suatu pola yang mencerminkan penerapan suatu formula; mengubah representasi yang digunakan pada pemecahan masalah, misalnya gambar - tabel - formula; dan melakukan gerakan anggota tubuh, mengerutkan dahi atau memicingkan mata yang menyiratkan kegiatan berpikir. Representasi eksternal yang digunakan siswa ketika memecahkan masalah kontekstual dan menjawab pertanyaan wawancara pada pra-survey, antara 
lain : gambar statis, tabel, simbol tertulis, bahasa tulisan dengan kalimat sendiri, melakukan gerakan fisik seperti menggerakkan tangan sambil meng-gumam, atau mendongakkan kepala sambil mengerutkan dahi. Tentu ada banyak hal terjadi dalam benak siswa yang mendasari pembentukan representasi eksternal dalam memberi respon atau melakukan aktivitas, baik ketika memecahkan masalah konteks-tual maupun ketika menjawab pertanyaan wawancara.

\section{Metode}

Untuk mengungkap dan menjelaskan fenomena tingkah laku responden menang-kap ide-ide dan menyatakan dalam berbagai representasi, penelitian ini menggunakan metode pencapaian pengertian berdasarkan interpretasi tingkah laku yang bersangkut-an (Miles dan Huberman, 1994). Penelitian ini lebih memperhatikan proses dari pada hasil, serta memusatkan perhatian pada suatu pemaknaan, dan memandang upaya pe-mahaman tingkah laku siswa dalam merepresentasikan ide-ide matematika yang ter-kandung pada masalah kontekstual sebagai suatu kasus, meskipun bukan merupakan kasus yang baru sama sekali. Dengan karakteristik seperti itu, maka penelitian ini dapat dikategorikan sebagai penelitian kualitatif (Lincoln \& Guba, 1994; dan Bogdan \& Biglen, 1982). Responden pada penelitian ini adalah satu orang anak yang berstatus sebagai siswa kelas 2 SMP. Pemilihan responden didasarkan pada pertimbangan bahwa yang bersangkutan bersedia menjawab masalah kontekstual yang diberikan kepadanya dan bersedia diwawancarai secara mendalam berkaitan dengan lembar jawaban masalah. Masalah kontekstual yang dikembangkan menjadi perangkat untuk mengamati aktivitas responden dalam memahami ide-ide matematika berkaitan de-ngan topik persamaan linier bentuk ax $+\mathrm{b}=\mathrm{c}$ seperti berikut.

Pada acara perpisahan siswa kelas 3, panitia menyediakan 17 dos minuman Aqua kemasan gelas plastik. Kepala sekolah memberi tambahan sebanyak 38 gelas plastik Aqua, sehingga persediaan minuman itu menjadi 854 gelas plastik Aqua.

Bagaimana caramu mengetahui banyaknya gelas plastik Aqua pada masing-masing dos, bila dos itu sama ukurannya?

Berapa banyak isi setiap dos?

Dengan mengacu pada kesempatan terjadinya matematisasi, konteks masalah tersebut dikategorikan konteks berorde dua (Lange, 1995), dan menurut derajat reali-tasnya masalah ini dapat dikategorikan sebagai masalah dengan konteks esensial. Berdasarkan hasil coba instrumen dapat dikemukakan bahwa 53, 66 \% siswa menyu-kai masalah ini dan sebanyak 56,09 \% menyatakan bahwa kegiatan perpisahan ini sering diselenggarakan di lingkungannya dan 4,88 \% menyatakan belum pernah me-nemui di lingkungannya. Jenis representasi yang mungkin digunakan siswa untuk memecahkan masalah adalah representasi konkrit / benda manipulatif, verbal dengan menggunakan kalimat secara tertulis atau lisan, gambar / sketsa, atau notasi formal. 
Untuk menangkap penafsiran tingkah laku responden menggunakan metode inter-pretatif understanding (Miles dan Huberman, 1994) untuk menginterpretasi fenome-na atau fakta-fakta yang muncul, yang direfleksikan atau dipolakan oleh responden ketika memecahkan masalah. Ada dua teknik pengumpulan data untuk menggambar-kan fenomena didaktik tersebut yaitu : (1) wawancara yang didasarkan tugas peme-cahan masalah, (2) pengamatan aktivitas alamiah selama pemecahan masalah. Wawancara juga dimaksudkan untuk meneliti kebenaran data, atau melengkapi data.

Dalam menganalisis data mulamula dideskripsikan tentang struktur episode pemecahan masalah untuk melihat konstruksi mental responden dalam mengorgani-sasi ide-ide dan pengembangan representasi selama proses pemecahan masalah yang berkaitan dengan konsep persamaan linier bentuk ax $+b=c$ Dalam mencermati model kompetensi responden dilakukan analisis struktur episode pemecahan masalah dengan menggunakan episode Schoenfeld (1985, 1992) dan Polya (1973). Sekuen pengembangan representasi dilakukan analisis bagian demi bagian sesuai dengan unit analisis masalah. Ada tiga unit analisis dalam proses pengembangan representasi, yaitu tahap inventive - semiotic, tahap pengembangan struktur, dan tahap otonomi.

Analisis perubahan-perubahan representasi selama menyelesaiakan masalah dila-kukan dengan mencermati berbagai representasi dan aktivitas yang diperlihatkan atau diisyaratkan oleh yang bersangkutan.

\section{Hasil-hasil Penelitian}

Struktur Episode Pemecahan Masalah

Dalam menyelesaikan masalah, mulamula responden (RA) memandang masalah yang dihadapkan kepadanya sebagai masalah aritmetika, sehingga dalam penyelesai-annya mula-mula menggunakan prosedur aritmetika dengan mengoperasikan bila-nganbilangan yang diketahui untuk memperoleh jawaban. Prosedurnya adalah mem-baca masalah $\rightarrow$ identifikasi informasi, membangun representasi verbal $\rightarrow$ merencanakan penyelesaian-1 $\rightarrow$ menerapkan rencana-1 $\rightarrow$ memeriksa ulang, menyadari ada kesalahan $\rightarrow$ memanggil ulang hasil identifikasi informasi dari struktur ingatannya $\rightarrow$ merevisi rencana penyelesaian-1 $\rightarrow$ menerapkan rencana $\rightarrow$ berhasil. Pada pengembangannya RA juga menggunakan prosedur aljabar dengan langkah-langkah : merencanakan penyelesaian-2 $\rightarrow$ menerapkan rencana-2 $\rightarrow$ memverikasi $\rightarrow$ berhasil. RA tidak menulis secara eksplisit dan lengkap prosedur penyelesaian pada lembar kerjanya, sebagian dilakukan secara mental di kepala.

Pada proses penyelesaian, RA melakukan kesalahan hitung karena tidak cermat dalam mencari hasil pengurangan. Ia mendapat kemajuan dalam penyelesaian masalah setelah memanggil (retrieved) kompetensi perbendaharaan istilah dalam sistem verbal yang mendorongnya untuk memeriksa ulang pekerjaan dan mengulang algoritma sehingga berhasil mencapai tujuan yang ditetapkannya. Pengembangan 
representasi dilakukan RA dalam beberapa tahap ketika menggunakan prosedur aljabar. Pengembangan dilakukan dari representasi verbal ke representasi dalam bentuk persamaan retorika, kemudian dikembangkan lagi menjadi representasi dalam bentuk syncopated dan kemudian menjadi representasi simbolik dalam sistem notasi formal. Pengembangan representasi dilakukan setelah berhasil memanggil ulang konsep peubah dari memori, yang menjadi titik tolak untuk mengubah (transformasi atau translasi) representasi-representasi yang ia perlukan dalam pemecahan masalah. Struktur episode pemecahan masalah oleh RA tersebut bila dinyatakan dalam diagram alur seperti berikut.

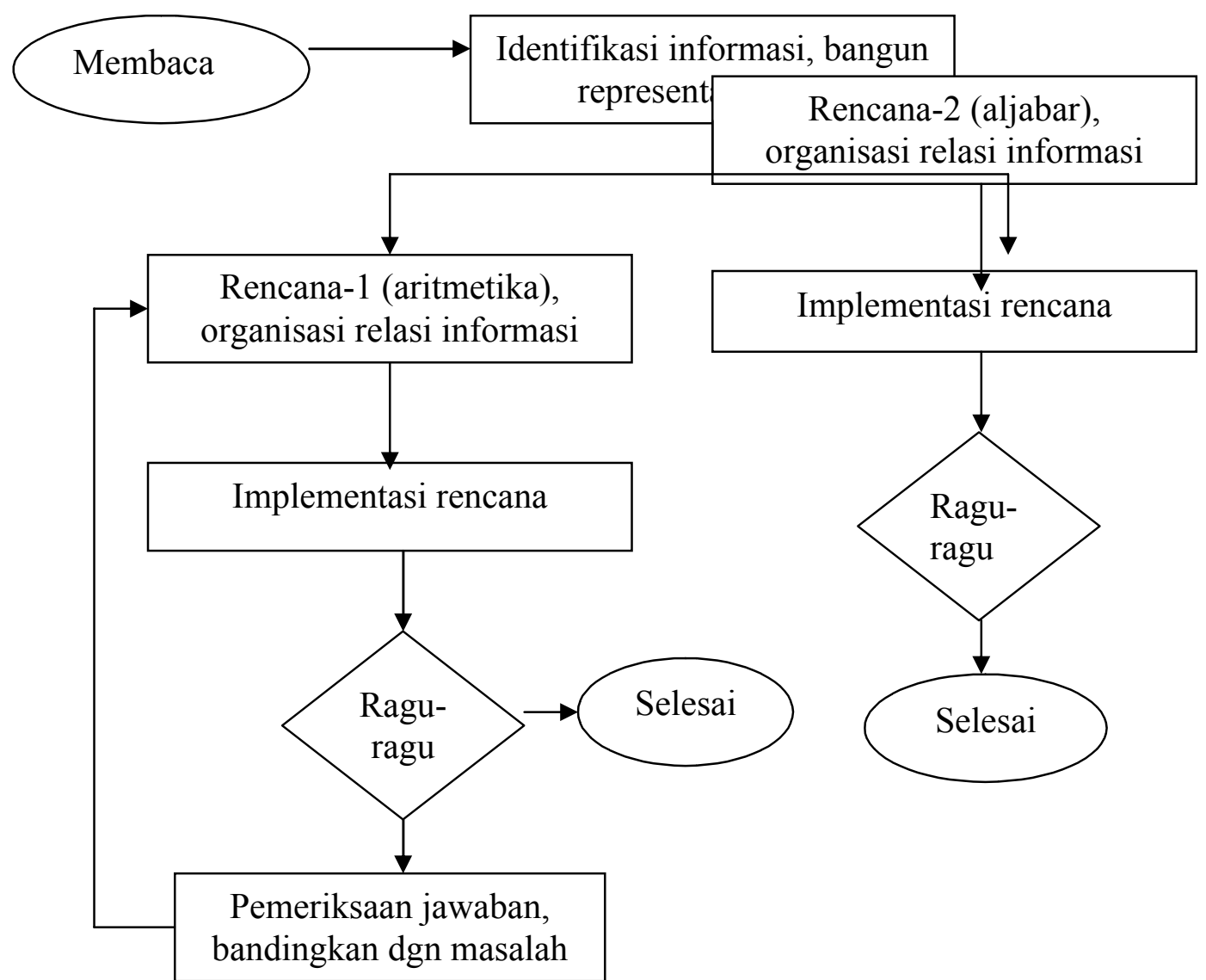

Gambar 1. Diagram alur struktur episode pemecahan masalah oleh RA

\section{Analisis Proses Pengembangan Representasi}

Tahap inventive-semiotic :

RA menangkap masalah yang dihadapinya setelah ia membaca berulang-ulang sebanyak tiga kali, ia menangkap intisari masalah berdasar sintaks informasi. Kemampuannya menangkap sintaks informasi itu menuntun RA untuk mengkons-truk imagery atau skema image kemudian mengungkapkannya secara verbal. Dalam mengkonstruk sistem imagistik RA memaknai informasiinformasi yang disediakan pada masalah sehingga ia dapat memilah istilah yang bermakna dan yang tidak bermakna dan membangun 
representasi verbal sampai. Aktivitasnya itu dilakukan RA secara internal, dan tidak dinyatakan secara eksternal pada lembar jawaban.

Penjelasan RA tentang dos bermuatan daya cipta istilah baru yang menjadi pendorong baginya untuk mengkonstruk label dari sistem representasi verbal. Ia memberi label peubah untuk dos yang belum diketahui isinya. Meskipun ia tidak bisa memberi penjelasan atau batasan tentang peubah, namun secara konseptual dapat membedakan antara contoh dan bukan contoh peubah. Pengetahuan RA pada konsep peubah menjadi pemandu baginya mengkonstruk sistem notasi formal untuk mere-presentasikan permasalahan yang dihadapinya.

\section{Analisis Pengembangan Struktur}

Representasi verbal yang dibangun RA ketika membaca soal digunakan untuk mengidentifikasi informasi ensensial dan membangun relasional di antara informasi tersebut dalam bentuk persamaan aljabar retorika. Aktivitas pengembangan repre-sentasi itu dilakukan secara internal di benak pikiran, ia tidak menuliskan secara eksplisit pada LKS. RA juga melakukan aktivitas prosedural komputasi aljabar retorika secara mental dengan melakukan transformasi representasi dari "panitia menyediakan tujuh belas dos, dapat tambahan tiga puluh delapan dari kepala sekolah, kan jumlahnya menjadi delapan ratus lima puluh empat" menjadi "delapan ratus lima puluh empat dikurangi tiga puluh delapan itu ada tujuh belas dos". Representasi retorika tersebut merupakan bagian dari rencana untuk mencari jawab numerik dari masalah. Tujuan yang ingin dicapai adalah meng-etahui banyak Aqua kemasan gelas plastik pada tujuh belas dos tanpa tambahan dari kepala sekolah. Pada lembar kerjanya ia mengubah (mengembangkan) persamaan retorikanya dengan persamaan aljabar dalam bentuk syncopated.

RA melakukan pengembangan representasi berikutnya setelah ia menangkap unsur peubah pada permasalahan. RA dapat menunjukkan peubah yang terdapat pada persamaan syncopated yang dibangunnya. Ia mampu mengembangkan representasi-nya sehingga terkonstruksi representasi simbolik dalam bentuk persamaan dalam sistem notasi formal.

\section{Analisis tahap otonomi}

Representasi verbal berbentuk persamaan aljabar retorika yang dibangun pada tahap sebelumnya dikembangkan RA menjadi persamaan syncopated, dan ditulis pa-da lembar kerja sebagai : 17 dos +38 gelas $=854$ gelas. Dengan representasi tersebut, RA menemukan tujuan akhir dari pemecahan masalah yaitu menemukan jawaban numerik untuk mengetahui isi dari masing-masing dos minuman aqua. Setelah membangun persamaan, RA mengintegrasikan dengan pengetahuan strategis yang dimiliki untuk merencanakan aktivitasaktivitas prosedural pemecahan masalah melalui transformasi representasi (RA (1.21)). Representasi berbentuk persamaan 
syncopated yang dibangun RA mencapai tahap otonomi ketika ia berhasil meng-integrasikannya dengan pengetahuan strategis sehingga ia dapat melakukan transformasi representasi untuk memperoleh jawab.

Representasi simbolik yang mula-mula dibangun RA dalam penyelesaian ma-salah adalah peubah dengan menggunakan huruf x. Dengan representasi simbolik atomik itu, RA mengembangkan lebih lanjut dengan cara mengkombinasikan dengan informasi lain sehingga terbentuk relasi antar informasi menjadi persamaan linier satu variabel. Representasi yang dibangun RA dapat mencapai tahap otonomi setelah representasi tersebut dapat ditempatkan pada sistem relasi-relasi simbolik, RA berhasil melakukan transformasi representasi sehingga diperoleh jawaban numerik.

\section{Analisis Perubahan Representasi}

\section{Analisis}

perubahan representasi oleh RA selama menyelesaikan masalah dilaku-kan dengan mencermati berbagai representasi dan aktivitas yang diperlihatkan atau diisyaratkan olehnya. Untuk ini perlu pengkodean berikut : representasi yang digunakan oleh responden dikode $\mathbf{R}_{\mathbf{I N T}}$ untuk representasi internal; dan $\mathbf{R}_{\text {EKS }}$ menyatakan representasi ekternal. $\mathbf{R}_{\mathbf{I N T}}$ diketahui dari ungkapan lisan responden. $\mathbf{A}_{\text {INT }}$ menyata-kan aktivitas internal responden, $\mathbf{A}_{\mathbf{E K S}}$ menyatakan

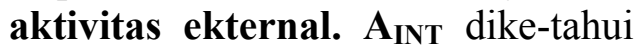
dari ungkapan lisan atau diisyaratkan oleh yang bersangkutan.
Setelah membaca (A $\left.\mathbf{A}_{\text {EKS-1 }}\right)$ dan memahami masalah dengan membangun repre-sentasi verbal, dan $\mathbf{R}_{\mathbf{I N T}}$, RA membangun relasional struktur masalah dalam persamaan aljabar retorik $\left(\mathbf{R}_{\mathbf{I N T}}\right)$. Secara internal dalam sistem imagistik, RA mengidentifikasi informasi untuk ditemukan (pertanyaan). Informasi itu ditetapkan sebagai tujuan antara dan menjadi bagian dari rencana penyelesaian. $R A$ menerapkan representasi internal tactile (A $\left.\mathbf{A}_{\text {INT }}\right)$ ketika ia melakukan transformasi representasi secara internal $\left(\left(\mathbf{R}_{\mathbf{I N T}}\right) \rightarrow\left(\mathbf{R}_{\mathbf{I N T}}\right)\right)$ dengan mengubah persamaan aljabar retorika : "panitia menyediakan tujuh belas dos, dapat tambahan tiga puluh delapan dari kepala sekolah, kan jumlahnya persediaan men-jadi delapan ratus lima puluh empat" (17 dos $+38=$ 854) menjadi "delapan ratus lima puluh empat dikurangi tiga puluh delapan itu ada tujuh belas dos" (854-38=17 dos).

\section{Analisis :}

RA mengimplementasikan (menulis) rencana pemecahan masalah (A $\left.\mathbf{A}_{\text {EKs-2 }}\right)$ de-ngan menggunakan prosedur aritmetika. Setelah menyelesaikan pembagian $(716: 17)=42,141$ pada lembar coretan kemudian RA mengerutkan dahi, meragukan jawaban numerik hasil kalkulasi yang ia peroleh. Dengan jawaban itu, RA terdorong memanggil ulang kompetensinya pada sistem verbal / sintatik ( $\left.\mathbf{R}_{\mathbf{I N T}}\right)$. Istilah kunci yang menjadi dasar berpikirnya adalah dos diketahui berukuran sama. Ia memban-dingkan antara dos yang berisi gelas aqua berukuran sama dengan hasil kalkulasi numerik berupa bilangan 
desimal. Ia menyadari adanya kesalahan hitung, dan memutuskan untuk mengulangi prosedur kalkulasinya.

Untuk memeriksa ulang hasil dan prosedur pembagian, mula-mula RA memi-kirkan untuk memeriksa ulang hasil pengurangan (854-38) = ... (R $\left.\mathbf{R}_{\mathbf{I N T}}\right)$. Namun, pada lembar coretan RA tidak melakukan pengurangan, tetapi mengubah representasinya dengan representasi penambahan $(716+38)=\ldots\left(\mathbf{R}_{\mathbf{E K S}}\right)$ untuk mengetahui kebenaran $(716+$ $38=816$ ) (AEKS). Dari pemeriksaan ulang itu ia mengetahui penyebab kesa-lahan karena tidak cermat dalam pengurangan, dan memutuskan untuk mengulangi kalkulasi pembagian. Ketika melakukan pembagian 816 oleh 17 (AEKS) RA tidak me-nyelesaikan secara tuntas. Setelah memperoleh 136 sejenak menghentikan operasinya dan memainkan bola matanya. Ia membagi 136 oleh 17 secara mental (RA(1.38) (A $\mathbf{A}_{\text {INT }}$ ). Untuk mendapatkan hasilnya, ia menggunakan ope-rasi kebalikan dari pembagian. Dengan coba-salah RA mencari hasil perkalian $17 \times 4=$ $\ldots, 17 \times 5=\ldots, 17 \times 7=119$ (A $\left.\mathbf{A}_{\mathbf{E K S}}\right)$, dan secara rekursif diperoleh $17 \times 8=136(\operatorname{RA}(1.41))$.

RA melakukan perubahan representasi lagi setelah dapat mengasosiasikan informasi yang didapat dari masalah dengan pengetahuan yang ada dalam memori-nya. Ia mentranslasi (A $\mathbf{A}_{\text {INT }}$ ) dari representasi verbal (dos) $\left(\mathbf{R}_{\mathbf{I N T}}\right)$ menjadi representasi simbolik (x) $\left(\mathbf{R}_{\mathbf{I N T}}\right)$; dan melanjutkan dengan mengubah ( $\left.\mathbf{A}_{\text {INT }}\right)$ representasi dari persamaan retorik $\left(\mathbf{R}_{\mathbf{I N T}}\right)$; menjadi persamaan syncopated ( $\left.\mathbf{R}_{\mathbf{E K S}}\right)$ dan dikembangkan lagi menjadi persamaan simbolik (lihat gambar 4.1) ( $\left.\mathbf{R}_{\text {EKS }}\right)$. Perubahan lebih lanjut dilakukan RA untuk mendapat jawaban numerik dengan operasi aljabar. Dinamika perubahan aktivitas dan representasi dalam pemecahan permasalahan seperti berikut.

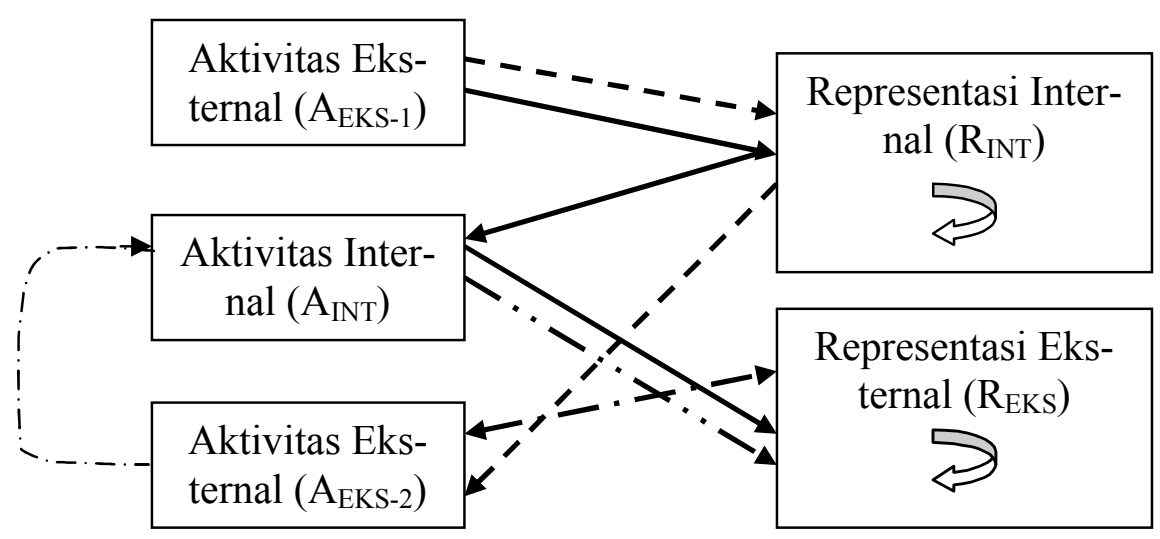

Gambar 2. Bagan Simpulan 
Alur pengembangan representasi yang dilakukan oleh responden ketika meme-cahkan masalah diawali dengan membangun imagery dalam sistem imagistik untuk memaknai informasi-informasi yang tersedia dan membangun representasi verbal. Hubungan di antara informasi-informasi dinyatakan dalam representasi berbentuk persamaan retorika, kemudian dikembangkan menjadi bentuk persamaan syncopated. Pemberian label peubah untuk istilah esensial yang tersedia pada masalah (dos) merupakan daya untuk membangun simbol atomik (ia menggunakan huruf $\mathrm{x}$ ), dan merupakan unsur penting untuk dikembangkan menjadi notasi simbolik dalam bentuk molekuler. Representasi yang dibangun oleh RA dapat mencapai tahap otonomi sete-lah hasil pengembangan representasi tersebut dapat ditempatkan pada sistem relasi-relasi simbolik, sehingga berhasil melakukan transformasi representasi dan memper-oleh jawaban numerik.

Selama berlangsungnya pemecahan masalah, RA melakukan beberapa kali peru-bahan representasi. Perubahan represenatsi tersebut didorong oleh : tujuan yang ingin dicapai, baik tujuan antara (jangka pendek) maupun tujuan akhir; image tentang per-samaan aljabar retorika dalam sistem imagistic tactile yang menjadi penggendali bagi RA untuk mentransformasi representasinya; ketidakseimbangan dalam stuktur kogni-tif; kompetensi RA dalam mengasimilasi informasi pada masalah dengan pengeta-huan yang tersimpan dalam struktur kognitifnya (peubah); prosedur yang telah biasa digunakan responden dalam menyelesaikan masalah; serta sifat-sifat dan relasi kesa-maan dari struktur aritmetika atau aljabar.

\section{DAFTAR PUSTAKA}

Bogdan, R.C. \& Biglen S.K. (1982). Qualitative Research for Education : An Introduction to Theory and Methods. Needham Heights, MA : Allyn and Bacon.

Goldin, G.A. (1987a). Levels of Language in Mathematical Problem Solving. In Claudia Janvier. Problem of Representationin the Teaching and Learning of Mathematics. Hildale, NJ : Lawrence Erlbaum.

Goldin, G.A. (1987b). Cognitive Representational System for Mathematical Problem Solving. In Claudia Janvier. Problem of Representationin the Teaching and Learning of Mathematics. Hildale, NJ : Lawrence Erlbaum.

Hartoyo, A. (2002). Apa yang Diperoleh Anak Ketika Dihadapkan Pada Masalah Kontekstual. Hasil Pra-Survey. Surabaya : UNESA.

Hiebert, J. \& Carpenter, T.P. (1992). Learning With Understanding. In Grouws D.A. (ed). Handbook of Research on Mathematics Teaching and Learning, A Project of NCTM. New York : Macmillan.

Janvier, C. (1987). Conceptions and Representations : The Circle as an Example. In Claude Janvier (editor). Problems of Representation in the Teaching and Learning of Mathematics. Hillsdale, NJ : LEA.

Kaput, J. (1987). Representation Systems and Mathematics. In Claude Janvier (editor). Problems of Representation in the Teaching and Learning of Mathematics. Hillsdale, NJ : LEA. 
Lesh, P.;Post, T.; \& Berh, M. (1987). Representation and Translation Among Representation in Mathematics Leraning and Problem Solving. In Claude Janvier (editor). Problems of Representation in the Teaching and Learning of Mathematics. Hillsdale, NJ : LEA.

Lincoln, Y.S \& Guba, E.G. (1985). Naturalistic Inquiry. Baverly Hills, California : Sage.

Miles, M.B. \& Huberman, A.M. (1994). Qualitative Data Analysis : An Expanded Sourcebook. $2^{\text {nd }}$ ed. Thousand Oak, CA : Sage.

NCTM. (2000). Principles and Standards for School Mathematics.Drive, Reston, VA.

Thomas, N.D., Mulligan, J.T., \& Goldin, G.A., (2002). Children's Representation and Structural Development of the Counting Sequence $1-100$. www.sciencedirect.com/science/Journal.

Yamada, A. (2000). Two Patterns of Progress of Problem-Solving Processes : From a Representational Perspective. Email : yamada@auecc.aichi-edu.ac.jp 